\title{
IAMJ
}

INTERNATIONAL

AYURVEDIC

MEDICAL JOURNAL

\section{TOBACCO PRODUCTS: CHEMICAL ANALYSIS AND COMPARATIVE HARMFULNESS}

\author{
Sunita Kumari Bijarniya ${ }^{1}$, Ritu Kapoor ${ }^{2}$, Manoj Adlakha ${ }^{3}$ \\ ${ }^{1}$ MD Scholar, P.G. Dept, Agad Tantra evam Vyavahar Ayurveda, DSRRAU, Jodhpur, Rajasthan, India \\ ${ }^{2}$ Associate Professor, P.G. Dept Agad Tantra evam Vyavahar Ayurveda, DSRRAU, Jodhpur, Rajasthan, India \\ ${ }^{3}$ Associate Professor, P.G. Dept Agad Tantra evam Vyavahar Ayurveda, DSRRAU, Jodhpur Rajasthan, India
}

Corresponding Author: bijju457@gmail.com

\section{https://doi.org/10.46607/iamj1409042021}

(Published Online: April 2021)

Open Access

(C) International Ayurvedic Medical Journal, India 2021

Article Received: 18/03/2021 - Peer Reviewed: 13/04/2021 - Accepted for Publication: 18/04/2021

Check for updates

\section{ABSTRACT}

Tobacco consumption is a major social health problem in India as well as throughout the world, because it harms both health and wealth of an addict. Tobacco is a Sthavara Patra Visha received from the plant Nicotiana tobacum/ Nicotiana rusticum leaves by curing them. Tobacco contains an alkaloid nicotine in abundant amount, which is sufficient to make addict like alcohol, cocaine and morphine. There are so many different forms of smoking and smokeless tobacco in India, like cigarette, bidi, gutka, jarda, pan masala etc. Long timed use of Tobacco like adductive products by oral route, acts as a slow poison (Dushi Visha) induces chronic toxicity to the gastrointestinal tract like oral diseases, gingivitis and periodontitis, Leukoplakia (precancerous stage), and may lead to cancer also in advance stage. This chronic toxicity affects cardiovascular system and results as increasing coronary blood flow, heart rate and blood pressure which may trigger the chances of heart attack rate in addict person. Before we can do any effort for reducing toxicity produced by tobacco products its mandatory to knowing the basic knowledge of tobacco products, their chemical composition, their mechanism of action with comparative toxicity and specific tobacco product related to a specific mouth part cancer. Because we can't stop a person to start tobacco use but we can circulate the knowledge of tobacco products in adolescent groups so that when the beginner chose a tobacco product, he will be aware about the toxicity and affecting organ because of its use. So that, the toxicity can be minimised. 
Keywords: Tobacco consumption, nicotine, slow poison, cancer, comparative toxicity

\section{INTRODUCTION}

At present, oral cancer is one of the topmost happening cancers in both sex. Tobacco use is the major cause of oral cancer. Tobacco is a cardiac vegetable poison. It is an addictive substance but not a madkaari, as tobacco use doesn't losses the intellectual (buddhi) of user. Tobacco contains alkaloids like- 1) Dried leaves contain $1-8 \%$ of nicotine, 2) Anabasine, 3) Unburned cured tobacco- nicotine, carcinogens, 4) Burned smoke- carbon monoxide, respiratory irritant. Tobacco causes both acute and chronic toxicity dependent on the dose intake. Here the paper focus is mainly on tobacco products study and their related chronic toxicity.

\section{Oral Cancer Incidence-}

Compared to western countries, India has high incidence of oral cancer. The incidence rate in India is 44.8 and 23.7 in male and female ${ }^{1}$. About $80 \%$ of patients with oral cancers use tobacco in the form of cigarettes, chewing tobacco or snuff. Smoking may lead to cancer in lung mouth or throat and oral tobacco products are associated with cancer in the cheeks, gums and inner surface of the lips. Oral cancer is twice as common in men as in women as the addiction of both alcohol and tobacco is seen commonly in men. ${ }^{2}$

\section{Hazards related to Tobacco habit-}

$>$ Smoking and alcohol both increase the risk of oral cancer six times.

$>$ Tobacco chewing is counted as the second most reason of sub mucous Fibrosis (OSF).

$>$ Betel quid without tobacco also increases the risk of oral pre- cancerous fibrosis relative to leukoplakia, erythroplakia or multi pre- cancerous lesions. $^{3}$

$>$ Reverse smoking causes thermal trauma and is a cause of ulcers of the oral cavity.

$>$ Smoking increases peri-odontitis (upakusha) and bleeding gums (paridar).

$>$ Leukoplakia, hairy tongue and Nicotine Stomatitis are primarily caused by the use of tobacco. ${ }^{4}$

$>$ Chronic toxicity affects cardiovascular system and nicotine alters the bioavailability of dopamine and serotonin which results as increasing coronary blood flow, heart rate and blood pressure which may trigger the chances of heart attack rate in addict person.

\section{Tobacco and its habit-}

Tobacco is an addictive and intoxicative material made up by drying the leaves of the plant Nicotiana tobacum/ Nicotiana rusticum. In many tobacco products fermented tobacco is used to enhance the efficacy of tobacco. After America and China, India is third in the production of tobacco. In India, Andhra Pradesh mostly produces it, other producers are Gujarat, Mysore, Bihar, Maharashtra, utter Pradesh and west Bengal. ${ }^{5}$

Vatanulomankar (relieving the collected gas of stomach), Basti shodhana (emptying the urinary bladder) and mood elevating properties make a person addict of tobacco because in every stress situation, he thinks the tobacco use as a helper to overcome the situation and many of them can suffer from acidity, appetite loss and constipation if they don't use the tobacco. ${ }^{6}$

1 to 2 grams of tobacco leaves don't create harmful effects in an addicted person ${ }^{7}$ (because the Nicotine tolerance in tobacco smokers is only $16-20 \mathrm{mg} / \mathrm{hr}$. which is one third of its fatal dose ${ }^{8}$ ), but the longer use of tobacco, develops many health hazards (Chronic Toxicity/ Dushivisha as agnimandhya, hrddaurbalya, Irregular kosthabaddhta and atisaar). According modern toxicology Fatal dose is 50- $100 \mathrm{mg}$ of nicotine/ 15- 30 gram of crude tobacco and fatal period is 5- 15 minutes. 5- 15 grams of tobacco leaves powder/ 1-5 drops of nicotine may happen poisonous and needed medical support. ${ }^{9}$

The Symptoms may be seen by chronic tobacco useNausea, vomiting, diarrhoea, headache, insomnia, Anxiety, Irritability, Tremors, Neuralgia, Contact dermatitis, Palpitation, coolness of hands and feet, Arteriosclerosis, low blood supply to extremities etc. and diseases like lung, oral, lip cancer, emphysema, 
lung disease( Bronchitis, chronic cough, asthma), Coronary diseases( MI, Angina, Cardiac arrhythmias) and immature delivery in mothers.

\section{Methods of Tobacco use in India-}

In India tobacco used in three most types-

1. Smoking Tobacco-
Mostly 5 types:
1). Hookah
2). Bidi
3). Cigarette

4). Cheroot 5). Cigar

Others are $=$ Chutta, reverse Chutta, Dhumti, Reverse Dhumti, Pipe, Hukli, Chillum

2. Chewing Tobacco-
Mostly 5 types:
1).Surti
2).Jarda
3).Kimam/
kiwam
4).Dokhta/ Jhundi
5).Sukkah

(Kimam is semi solid gel substances with silver ark and others are solid)

Others smokeless products are= Pan, Tobacco pan ( betel quid with tobacco), pan masala (with tobacco), Tobacco supaari and Slaked lime (bujha hua chuna) mixture, mainpuri tobacco, maava, Khaini (tobacco and Slaked lime mixture), chewing tobacco, mishri, Gul, bajjar, Gudhaku, tobacco water, Lal Dantmanjana etc.

3. Inhaling Tobacco- called sanas, snuff. Types like dry snuff (tapkeer), creamy snuff (with creamy tobacco powder)

In any inhaled form of tobacco, $90 \%$ of nicotine absorbed by body. Snuff is popular in west India and West Bengal.

Hookah- Also called water pipe/shisha/ Hubble bubble. In places with strong Mughal culture. Tobacco smoke is drawn through water in the base of hookah which cools and filters the smoke. Hookah is mostly used in North India, Punjab, Utter Pradesh, Bihar and Bengal. Now a days, Hookah is replaced by Cigarette. Bidi- 0.2 to 0.3 grams of sun-dried tobacco flakes are hand rolled in tendu leaf (palash leaf) (Bauhinia racemosa). Bidi is used by lower socio-economic persons. Bidis are found throughout south-east Asia and are India's most used type of tobacco.

Nicotine $=1.7$ to $3.0 \mathrm{mgs}$

Tar- 45 to $50 \mathrm{mgs}$

Cigarette- 1 gm of tobacco cured in the sun or artificial hand is covered with a paper. Most common in urban areas and available throughout the world. Filter (parallel cellulose fibres bunch) is only framed in cigarette and Filter-tipped cigarettes are usually more popular than unfiltered cigarettes. Cigarettes are India's second most used type of tobacco.

Nicotine- $1-1.4 \mathrm{mg}$

Tar- 19- $27 \mathrm{mg}$

E- Cigarette- In full electronic cigarette, batteryoperated device is modelled. In addition to the battery component, an e- cigarette comprises an atomizer and a cartridge containing either a nicotine or a nonnicotine liquid solution, when the device is operated, the battery heats the liquid in the cartridge, and the atomizer vaporizes the liquid, emitting it as a mist that the user inhales.

Cheroot- Cheroot is a thin cigar, open at both ends and about 3.5 inches long, usually thicker and stubbier than a panatela, and sometimes tapered. Panatela is a thin cigar, open at both ends, has a finished top that has to be cut off before smoking.

Cigar- Cigars are smoked throughout the world and generally are expensive. Regional variations include Cheroots and stumpen (western and central Europe) and Dhumtis (conical Cheroots) used in India.

A cylindrical roll of tobacco for smoking, consisting of cut, air cured, fermented tobacco 1) filler in a 2) binder leaf with a 3) wrapper leaf (tobacco leaf/ most expensive leaf) rolled spirally around the bunch. The cigar has one open end or has to cut one end before use and dimensions are 5.5 to 6 inches with a ring gauge of 42 (42/ 64 of an inch in diameter) to 44(44/ 64 of an inch in diameter).

Chutta- Cured tobacco is wrapped in a dried and fermented tobacco leaf. It is a local hand rolled cigar; the length varies from $5-12 \mathrm{~cm}$. It is also called as Cigar. Chutta revealed a high content of nicotine as comparing to cigarette and bidi.

\section{Reverse Chutta smoking-}

When the glowing end of the tobacco product is kept inside the mouth, is called Reverse Chutta smoking. It causes mouth ulcers and Nicotine stomatitis.

Dhumti- Rolled leaf tobacco inside leaf of jack fruit tree/ dried leaf of banana plant.

Pipe- Pipe smoking is an oldest trend of smoking, is the practice of tasting (or, less commonly, inhaling) the smoke produced by burning a substances, most 
commonly tobacco, in a pipe. It has been also suggested that the pipe smoker is going to suffer rather more than the cigar smoker. In Southeast Asia clay pipes known as suipa, chillum and hookli are widely used.

\section{Hukli-}

Small form of Hookah called as hukli, is a clay pipe. Chillum- A $14 \mathrm{~cm}$ straight conical clay pipe. Coarsely cut tobacco pieces about 5- 8 grams and a glowing charcoal is kept on top. It is held vertically and to prevent tobacco from entering the mouth a pebble stone is introduced. A thin cloth is used as filter.

Pan (betel quid)- Pan consists of four ingredients, betel leaf, areca nut, slaked lime, catcchu. Tobacco became an important constituent of pan, and currently most habitual pan chewers include tobacco.

Pan masala- Pan masala is a commercial preparation containing areca nut, slaked lime, catcchu and condiments, with or without powdered tobacco. Pan masala contains all the ingredients that go into the making of a pan but are dehydrated so that the final product is not perishable, it is available in attractive sachets and tins.

Surti- In India, Tobacco is mostly used by common people as surti. The word surti is used in Gujarat mostly, In India, it's called a tobacco pan in general. Tobacco became an important constituent of pan, and currently most habitual pan chewers include tobacco. The tobacco is placed on pan leaf and kept between the teeth and lips and its juice is sucked slowly. It has a delicious and fragrant form of tobacco.

Jarda- It is used by specific category person. It is the wide form of surti and used with pan.

Kimam- It is also used with pan but used rarely. It is gem like semisolid substance containing silver ark with the taste of peppermint. ${ }^{10}$

Dokha/ Dokhta/ jhundi- Dokha ( Arabic: dizziness/ vertigo) is an Arabian tobacco product, consisting of dried and finely shredded tobacco flakes mixed with herbs and spices, It originated in Iran during the $15^{\text {th }}$ century. Unlike hookah, dokha is not cured with molasses. Users smoke the tobacco blend in small quantities using a pipe called midwakh (pipe almost exclusively used for smoking dokha). ${ }^{11}$
Sukkah- Sukkah is a stimulant of the mind and body, it's a sacred drink of the shaheeds .Sukkah can help people away from drugs/ alcohol/tobacco products and will cure many other mental and physical issues in humans as is a sacred blend of herbs with the special "MA BHOOTI" mother plant Cannabis indica which was in existence before mankind. Also, the THC Receptor in the brain can only be activated by MA BHOOTI to release the penal gland known in meditation as the $3^{\text {rd }}$ eye or the 10th door. Sukkah is only herb that can do this and is non-addictive contrary to people viewpoints. ${ }^{12}$

Maava- Maava is a product made of wet thin shavings of areca nut, tobacco, Chuna, Fragrant.

Khaini- It's a lower grade tobacco product (called Chaitanya Churna also) and used independently. Generally, it is used by people in the early morning before going to toilet. Tobacco leaves are placed on the palm is crushed into powder and mixed with slaked Lime (chuna) with thumb and placed inside the lower lip. It is just placed there but not sucked and at the end its collected saliva is spit out of mouth and the remaining tobacco dung also spit out.

Manipuri tobacco- In the Manipuri district of utter Pradesh and nearby areas, this preparation is very popular. It contains mainly tobacco, with slaked lime, finely cut areca nut, camphor and cloves.

Gul- Gul is taken alone/ with gutkha also. Gul is an oral tobacco powder which is rubbed over the gum and teeth.

Gutkha- Gutkha is mixture of betel nut, Limestone, Kattha, tobacco, Crushed glass and Lime used for flavouring agent, used for chewing.

Gudukhu- Paste of powdered tobacco, molasses and other ingredients (to clean the tooth), used among women in Bihar.

Snuff/ Nass/ Naswar/ niswar/ Sunghani/ Snus- It is made by mixing many fragrant things into the small tobacco leaves. Snuff is placed between two front fingers/ in snuff box of hand or buccal/ labial groove and inhaled forcefully keeping it in front of the nostrils. Snuff is translated to snus in Swedish and mostly moist snuff is snus. 
Plug- Less common cured tobacco leafs pressed together into a cake or plug form and wrapped in a tobacco leaf. Piece taken from pouch and placed between cheek and gums.

Mishri- This practice is common in Maharashtraian women, when used it to clean their teeth. Mishri is a roasted, powdered preparation made by baking tobacco on a hot metal plate until it is uniformly black.

Bajjar- Bajjar is a dry snuff (tapkeer) applied commonly by women in Gujarat on the teeth and gums.

Creamy snuff- It is a commercial preparations of tobacco paste used as toothpaste in Goa for cleaning teeth, the user soon become addicted.

Lal Dantmanjana- It is a red colour powder, traditionally it is used to clean the teeth.

\section{Nicotine $\%$ in different tobacco products-}

\begin{tabular}{|c|c|}
\hline Bidi & 6- $8 \%$ (Highest Nicotine $\%)$ \\
\hline Cigarette & $1-2 \%$ (Second highest Nicotine $\%)$ \\
\hline Cigar & $2-3 \%$ \\
\hline Cheroot & $3-4.7 \%$ \\
\hline Hookah & $0.5-1.5 \%$ \\
\hline Shunghni/ Snuff & $\begin{array}{l}3.2-4.8 \%(20-30 \mathrm{mg} \text { nicotine } \\
\text { inhaled in body by this method) }\end{array}$ \\
\hline
\end{tabular}

Hookah vapour is inhaled after passing through water, so, it's mostly nicotine is mixed into water and less nicotine concentration is taken by a hookah user. ${ }^{13}$

Tobacco and its smoke Constituents in General-

- Nicotine $\left(\mathrm{C}_{10} \mathrm{H}_{14} \mathrm{~N}_{2}\right)$ - Most Addictive

- Tar

- Carbon Monoxide- CO

- Nitrogen Oxide

- Hydrogen cyanide and other toxic metals (CdCadmium, Pb- Lead, Arsenic, $\mathrm{Cu}, \mathrm{Co}$ )

- Radioactive compounds such as polonium- 210

- Fertilizers like nitrates

- Phenol, benzene, formaldehyde

- PAHs (poly cyclic Aromatic Hydrocarbons)

- TSNAs (Tobacco specific nitrosamines) ${ }^{14}$

Chemical Analysis of Tobacco Products- Nicotine is highly addictive chemical found in the tobacco plant itself and is therefore present in all tobacco products.
Chemicals in Cigarette- Some chemicals - along with nicotine- are found in the tobacco plant itself. As tobacco plant grows it absorbs chemicals like- $\mathrm{Cd}, \mathrm{Pb}$ and Nitrates, from the soil and fertilizers. As tobacco leaves are cured, dangerous chemicals can form, these chemicals called TSNA's (Tobacco specific nitrosamines), remain in the tobacco leaves after the curing process.

During manufacturing, ammonia added to increase absorption. Sugar and flavour additives may also be added during this stage to mask the harshness the smoke. These additives form cancer- causing chemicals when they are burnt.

\section{Chemicals in Hookah-}

Except the cigarette chemicals, hookah contains CO, metals and other carcinogens

\section{Chemicals in smokeless tobacco-}

Smokeless tobacco although not combustible, contains a mix of 4000 chemicals including as many as 30 or more that are linked to cancer. These chemicals include heavy metals, cadmium. Lead and nickel; as well as arsenic, Formaldehyde, N- Nitrosonornicotine (NNN).

\section{Chemicals in E- Cigarettes-}

Preliminary studies suggest switching completely to Ecigarettes could be less harmful than combustible cigarettes for adults who already have a nicotine addiction. Most E- Cigarettes contain nicotine. Other chemicals like formaldehyde, acrolein and acetaldehyde are also found in some E- Cigarettes aerosols. E- Cigarettes can also contain flavouring agents such as diacetyl and acetoin. ${ }^{15}$

The FDA (the food and drug administration) has also established the list of 93 (HPHC's- Harmful and Potentially harmful constituents in Tobacco Products and tobacco smoke) in April 2012. Which are CA (carcinogen), RT (respiratory Toxicants), CT (Cardio vascular Toxicants), RDT (reproductive or developmental toxicant), $\mathrm{AD}$ (addictive) as required by federal food, drug and Cosmetic Act (the FD \& C Act). ${ }^{16}$

Effects of Smoking- Smoking is a mood elevator, reduces the tension and gives psychological satisfaction. Although, just after smoking both blood pressure and pulse increase and skin temperature falls. 
But these effects are Short timer. Smoking increases the mental efficiency, sense of wellbeing and tranquillization.

About Toxicity of Cigarette Smoking - A study shows that the mouth end of cigarette contains 15 times more $\mathrm{CO}_{2}$, than the burning end. $9 \mathrm{mg}$ nicotine is left on burning end and $0.2 \mathrm{mg}$ of nicotine is left on mouth end. Thus enough nicotine is used on smoking the cigarette. A rapid smoke of cigarette is more dangerous than slow because more inhale of nicotine on fast and forceful smoking. The stomach and lung carcinogenic irritants in cigarettes are Benzopyrene. Some of cigarette smokers exhale the cigarette smoke and some inhale, the nicotine of inhaled smoke, absorbed by the mucous membrane of lungs and being in the touch of the pleural membrane it stops the gaseous supply and exchange of the membrane cells and causes more toxicity as like cancer.

\section{Types of Smokers -}

One classification shows two type smokers-

1). Lusty- smoke for own satisfaction and habit.

2). Tense- Smoke for reducing tension and to get nicotine.

Some Scientists divide smokers into 3 categories-

1) Associative Smokers- Smoke to associate others, easily can leave smoking.

2) Neurotic Smokers- They are mentally dependent on smoking and can't leave smoking.

3) Toxophillic Smokers- Their body symptoms are controlled by nicotine and the abstinence symptoms can be produced if smoking is avoided. So, it is mandatory to smoke for them.

Tobacco product related to specific organ cancer-

Pipe Smoke- Lip cancer

Cigarette Smoke- Larynx, tongue, elementary canal, Lung

Cigar Smoke- Oral cancer

Khaini Smoke- Gum and Lip inside cancer ${ }^{17}$

\section{DISCUSSION}

All tobacco products discussed with their nicotine percentage and related mouth part cancer. It is best for a person not to tobacco use, but if does, he should avoid highest nicotine percentage tobacco products use, filter less and cheap tobacco products smoking, reverse smoking, fast and forceful smoking, and inhalation of smoke etc. So that excess lung damage can be stopped. The Lusty and Associative smoking are the initiative stages of addiction, they should not go ahead to the strong addiction by stopping smoke for just show off or enjoy in parties and anyone not to be forced for smoking by colleagues/ friends. Because it may lead to a great danger to your dear one.

\section{CONCLUSION}

The tobacco is used widely in many forms as required taste although knowing that its use is harmful. The nicotine percentage and comparative harmful ness of tobacco products should be studied by a smoker before choosing a product So that the toxicity can be made at its minimum.

\section{REFERENCES}

1. PL Dhingra - Diseases of EAR, NOSE, and THROATChapter 43-Tumours of Oral Cavity, published byELSEVIER A division of reed Elsevier India Private Limited, New Delhi- 110065 India-2007, Printed and bound at Gopsons Papers Ltd., Noida, Fourth edition, pg. No.210

2. Risk Factors of Oral Cancerhttps://www.cancercenter.com/cancer-types/oralcancer/risk-factors

3. PL Dhingra - Diseases of EAR, NOSE, and THROATChapter 43-Tumours of Oral Cavity, published byELSEVIER A division of reed Elsevier India Private Limited, New Delhi- 110065 India- 2007, Printed and bound at Gopsons Papers Ltd., Noida, Fourth edition, pg. No. 205

4. Dr. Rajbir Singh- Textbook of ENT- Shalakya Tantra (vol. 1\&2) combined (Diseases of eye) (Diseases of E.N.T.\& Head) Part 2- chapter 14- Dantamula gat rogas (Anatomy of teeth), published by Chaukhambha publications New Delhi- 110002 (India), 2016, Printed by- Globe Offset Press, New Delhi, edition-first, pg. no. 570,578

5. Priya Kumar Chaube- Madak Dravya- (Nasheele Padartha) Vyasan Avam Upchar (Drug Addiction and Treatment with Photographs\& Diagrams), chapter 23, Tambaku sevan (Tobacco habit)-published byChaukhambha Orientalia, Golghar, Maidagin,Varanasi221001 (UP) India, 2010,Printed by- Charu Printers, 
Golghar, Varanasi (UP), reprint edition: 2010 pg. no:109-111

6. Vaidya Laksmipati sastri- Yogratnakar- vidyotini hindi commentary, edited by Bhisagratna brahmasankar sastri purvardha Dhanyadifalkndshakgunah ath tamakhuguna, shlok 3-4-5 published by- Chaukhambha Orientalia, Golghar, Maidagin,Varanasi-221001 (UP) India- 2010, Printed by- Charu Printers, Golghar, Varanasi (UP), edition: 2010, pg.no.-35

7. Dr. Charuchandra Pathak- Vishvijnana, introduction by Prof. P.V. Sharma, second part- chapter no.5NadiPrabhavak Visha ( Neurotic Poisons)-(11)-tobacco published by- Chaukhambha Orientalia Varanasi221001 (UP) India-2001, Printed by- Charu Printers, Golghar, Varanasi (UP) $3^{\text {rd }}$ edition, pg. No. -119

8. Priya Kumar Chaube- Madak Dravya- (Nasheele Padartha) Vyasan Avam Upchar (Drug Addiction and Treatment with Photographs\& Diagrams), chapter 23, Tambaku sevan (Tobacco habit)-published byChaukhambha Orientalia, Golghar, Maidagin,Varanasi221001 (UP) India, 2010,Printed by- Charu Printers, Golghar, Varanasi (UP), reprint edition: 2010 pg. no:117

9. Dr. Charuchandra Pathak- Vishvijnana, introduction by Prof. P.V. Sharma, second part- chapter no.5NadiPrabhavak Visha ( Neurotic Poisons)-(11)-tobacco published by- Chaukhambha Orientalia Varanasi221001 (UP) India-2001, Printed by- Charu Printers, Golghar, Varanasi (UP) $3^{\text {rd }}$ edition, pg. No. -119

10. Priya Kumar Chaube- Madak Dravya- (Nasheele Padartha) Vyasan Avam Upchar (Drug Addiction and Treatment with Photographs\& Diagrams), chapter 23, Tambaku sevan (Tobacco habit)-published byChaukhambha Orientalia, Golghar, Maidagin,Varanasi221001 (UP) India, 2010,Printed by- Charu Printers, Golghar, Varanasi (UP), reprint edition: 2010 pg. no:109-112

11. Dokha- Wikipedia- en.m.wikipedia.orghttps://en.m.wikipedia.org/wiki/Dokha

12. Sukkah - the sacramental Cannabis Drink of the Nihang Warriors http://deghtegh.blogspot.co.uk/

13. Priya Kumar Chaube- Madak Dravya- (Nasheele Padartha) Vyasan Avam Upchar (Drug Addiction and Treatment with Photographs\& Diagrams), chapter 23, Tambaku sevan (Tobacco habit)-published byChaukhambha Orientalia, Golghar, Maidagin,Varanasi221001 (UP) India, 2010,Printed by- Charu Printers, Golghar, Varanasi (UP), reprint edition: 2010 pg. no:111- 113
14. Harmful chemicals in Tobacco Products- American Cancer Society- https:/www.cancer.org/cancercauses/tobacco-and-cancer/carcinogens-found-intobacco-products.html

15. Chemicals in Tobacco Products and your Health https://www.fda.gov/tobacco-products/healthinformation/chemicals-tobacco-products-and-yourhealth\#: : text $=$ In $\% 20$ addition $\% 20$ to $\% 20$ nicotine $\% 2 C$ $\% 20$ other, $\mathrm{a} \% 20$ result $\% 20$ of $\% 20$ these $\% 20$ chemicals

16. Harmful and potentially harmful constituents in tobacco products and tobacco smoke: Established listhttps://www.fda.gov/tobacco-products/rulesregulations-and-guidance/harmful-and-potentiallyharmful-constituents-tobacco-products-and-tobaccosmoke-established-list

17. Priya Kumar Chaube- Madak Dravya- (Nasheele Padartha) Vyasan Avam Upchar (Drug Addiction and Treatment with Photographs\& Diagrams), chapter 23, Tambaku sevan (Tobacco habit)-published byChaukhambha Orientalia, Golghar, Maidagin,Varanasi221001 (UP) India, 2010,Printed by- Charu Printers, Golghar, Varanasi (UP), reprint edition: 2010 pg. no:$115-117$

\section{Source of Support: Nil \\ Conflict of Interest: None Declared}

How to cite this URL: Sunita Kumari Bijarniya et al: Tobacco Products: Chemical Analysis And Comparative Harmfulness. International Ayurvedic Medical Journal \{online\} 2021 \{cited April, 2021\} Available from: http://www.iamj.in/posts/images/upload/777_783.pdf 